\title{
ORGANIZACINĖS KULTŪROS IR SOCIALINĖS ATSAKOMYBĖS RAIŠKA UAB ,KRETINGOS VANDENYS“
}

\author{
Jurgita Paužuoliené, ${ }^{1}$ Jolanda DaubarienE ${ }^{2}$
}

Klaipėdos universitetas, Klaipėdos valstybinė kolegija(Lietuva)

\begin{abstract}
ANOTACIJA
Organizacinè kultūra ir socialinė atsakomybė yra veiksmingos priemonės, darančios įtaką organizacijos veiklai ir rezultatams. Kai organizacijoje nustatytos tam tikros normos, principai, taisyklès ir vertybès, jos darbuotojai dirba našiau, geriau jaučiasi, mažeja nepasitikejjimo, ịtampos, nesaugumo pojūtis. Siekiama ištirti UAB „Kretingos vandenys“ organizacinès kultūros ir socialinès atsakomybės būklę, išsiaiškinant privalumus ir sunkumus, pateikiant rekomendacijų, kaip tobulinti analizuojamas sritis. Straipsnyje analizuojama, kiek darbuotojai yra susipažinę su organizacinės kultūros ịgyvendinimu organizacijoje. Aptariama socialinės atsakomybès nauda, privalumai ir sunkumai, su kuriais organizacijoje susiduriama. Vertinama, kokioms organizacinès kultūros ir socialinès atsakomybès sritims organizacijoje skiriamas didžiausias dėmesys.
\end{abstract}

PAGRINDINIAI ŽODŽIAI: organizacinè kultūra, socialinè atsakomybè, organizacija.

JEL KLASIFIKACIJA: M14, L2

Ivadas

Organizacinè kultūra apima visų darbuotojų pastangas, remiasi bendromis žmonių vertybėmis. Darbuotojai siekia dirbti organizacijose, kur su jais elgiamasi sąžiningai, paisoma jų interesų. Šiandien verslas kelia vis naujus reikalavimus, kad organizacijų veikla būtų skaidri, skatinamas pilietiškumas. Žmonès, suvokdami socialinès atsakomybès (SA) ir organizacinès kultūros reikšmę, savo veikloje dažniau pradèjo taikyti etiško ir skaidraus valdymo principus. Socialiai atsakinga organizacija ne tik prisideda prie aplinkosaugos, bet ir ịneša didelị indelị ị visuomenės geresnių gyvenimo sąlygų kūrimą, gerina darbuotojų darbo sąlygas, pritraukia ir išlaiko geriausius specialistus, vykdo skaidrų verslą. Organizacinè kultūra vienija organizacijos darbuotojus, gerina moralinę atmosferą darbe, didina darbuotojų pasitikẻjimą. Be šių bendrų privalumų, pati ịmonè neišvengiamai gauna didžiulę naudą, nes formuojamas geras ịvaizdis visuomenès akyse, kyla prestižas, didèja konkurencinis pranašumas. Lojalūs klientai, nauji potencialūs vartotojai ịpareigoja organizaciją veikti atsakingai, tuo tarpu organizacija ịsipareigoja vartotojams teikti aukštos kokybės paslaugas, o

1 Jurgita Paužuolienè - vadybos mokslų krypties doktorantė, Klaipėdos universiteto Socialinių mokslų fakulteto Vadybos katedros asistentè. Moksliniai interesai: organizacinė kultūra, įmonių socialinė atsakomybè, personalo valdymo problemos

Adresas: Minijos g. 153, LT-93185 Klaipeda

El. paštas: j.pauzuoliene@gmail.com

Tel.: +3706214 1916

2 Jolanda Daubariene - Klaipėdos valstybinès kolegijos Socialinių mokslų fakulteto Vadybos katedros lektorė. Moksliniai interesai: darbuotojų saugos ir sveikatos valdymo problemos

Adresas: Jaunystės g. 1, LT-91274 Klaipèda

El. paštas: jolanda.daubariene@gmail.com

Tel.: +37069831503 
tai lemia ne tik geresnius organizacijos finansinius rodiklius bet ir darbuotojų darbo kokybę, organizacijos veiklos plètrą.

Straipsnyje keliami probleminiai klausimai: kaip socialinè atsakomybė ir organizacinè kultūra ịgyvendinama UAB „Kretingos vandenys“; su kokiais sunkumais ir susiduria organizacijos, igyvendindamos organizacinę kultūrą ir socialinę atsakomybę UAB „Kretingos vandenys“, kokie jų privalumai?

Objektas: UAB „Kretingos vandenys“ organizacinè kultūra ir socialinė atsakomybe்.

Tikslas: ištirti UAB „Kretingos vandenys“ organizacinès kultūros ir socialinès atsakomybès būklę, išsiaiškinant privalumus ir sunkumus, pateikti rekomendacijas, kaip tobulinti analizuojamas sritis.

Uždaviniai:

- išanalizuoti organizacinę kultūrą ir socialinę atsakomybę teoriniu aspektu.

- ištirti UAB „Kretingos vandenys“ organizacinès kultūros ir socialinės atsakomybės įgyvendinimą išryškinant privalumus ir sunkumus, su kuriais susiduria organizacija.

Metodai: mokslinès literatūros analizè, sisteminimas, anketavimas, tyrimo duomenų analizė SPSS programa.

\section{Organizacinès kultūros ir socialinès atsakomybès teoriniai aspektai}

Organizacinè kultūra pasireiškia jos narių elgesiu, įsitikinimais, vertybėmis, požiūriais ir yra vertingas įmonès konkurencinio pranašumo šaltinis, nes ji formuoja organizacines procedūras, vienija organizacijos darbuotojų gebejjimus ị darnią visumą, siūlo sprendimus problemų, kurios kyla organizacijoms, ir taip gali padèti organizacijai pasiekti savo tikslus (Yilmaz, 2008, cituota: Ahmad, 2012; Ehtesham, Muhammad, Muhammad, 2011). Organizaciné kultūra gali vaidinti tiek teigiamą, tiek neigiamą vaidmeni pritraukiant ir išlaikant darbuotojus. Jei lyderiai supranta organizacinès kultūros vaidmenį ir jos valdymo naudingumą, tai gali sutelkti organizacijas veikti kartu, siekiant sėkmingos veiklos (Osland, Turner, Kolb, Rubin, 2007). Be to, pastebima, kad organizacinè kultūra gali suburti darbuotojus ị darnią ir stiprią komandą, dèl ko kyla organizacijos produktyvumas. Darbuotojai jaučiasi labiau motyvuoti siekti organizacijos tikslų. Apie organizacinę kultūrą galime spręsti iš organizacijos vertybių, pasakojimų ir mitų, sklandančių apie įmonę (Gregory, Harris, Armenakis, Shook, 2009; Gupta, 2011, Lee, Cartier, 2005), iš įmonès darbuotojų kalbos, ritualų, tradicijų, klimato, vyraujančio organizacijoje, bei kitų kultūros raiškos elementų (Šimanskienė, 2008; Chang, $\mathrm{Lu}, 2007)$.

Kiekviena organizacija puoselëja savitą, tik jai būdingą kultūrą, išskiriančią ją iš kitų organizacijų, suteikiančią jai konkurencinio pranašumo. Vienos organizacijos linkusios labiau rizikuoti, kitos labiau orientuotos ị pasyvų laukimą. Iš esmès organizacinè kultūra yra organizacijos „asmenybe்“. Akcentuotina, kad nemažai vadovų i kalbas apie organizacinę kultūrą žiūri abejingai ir mano, kad organizacinè kultūra turi mažai įtakos tokiems su verslu susijusiems dalykams kaip pelno gavimas, aukštos kokybės siekis ir pan. Tačiau faktai byloja, kad organizacinè kultūra yra vienas svarbiausių veiksnių, lemiančių sėkmingus organizacijos pokyčius ir nešančių ilgalaikę sèkmę. Atlikti tyrimai rodo, kad organizacinè kultūra yra svarbus ir nemažai ịtakos darantis reiškinys organizacijos darbo našumui, veiklos rezultatams, darbuotojų pasitenkinimui darbu ir pan. Organizacinè kultūra gali veikti kaip motyvavimo priemonè ar kaip priemonè, padedanti darbuotojams siekti organizacijos tikslų. Organizacinè kultūra padeda palaikyti atitinkamą darbuotojų atsidavimo ir intensyvumo lygị, kas dažnai būdinga sėkmingai organizacijai (Deal ir Kennedy, 1982; Silvertornas, 2004, cituota: Nango, Ikyanyon 2012). Ji tiesiogiai veikia tokius dalykus, kaip darbuotojų pasitenkinimas ir ịsipareigojimas, moralè, komandinis darbas bei organizacijos veiklos rezultatai (Macintosh, Doherty, 2007).

D. B. Lund (2003) atliko tyrimą, siekdamas išsiaiškinti, kaip organizacinè kultūra veikia darbuotojų pasitenkinimą. Autorius pabrèžia, kad siekdama išlaikyti konkurencinị pranašumą organizacija turi puoselèti santykius su darbuotojais. Ištirta, kad savo darbu patenkinti nelinkę jo palikti darbuotojai daug didesni dẻmesị rodo klientams, jų poreikiams. Svarbu pabrèžti, kad būtina ne tik puoselèti organizacinę kultūrą, bet būtina susitelkti ị aiškų tikslą išorinèje aplinkoje, kur ir kreipiama ta kultūra. Tai iliustruoja 1990 metais Europoje atliktas tyrimas (Stanic, Boyle, 2000), kai nagrinètos 24 paslaugų sektoriuje veikiančios organizacijos. Ty- 
rimas atskleidè, kad visos sèkminga veikla pasižymėjusios organizacijos turèjo aiškiai apibrèžtą, ị išorinị tikslą orientuotą organizacinę kultūrą.

Organizacinè kultūra veikia socialinę atsakomybę per organizacijos vertybių sistemą. Šios vertybės skatina atitinkamą individo elgesị organizacijoje. Tiriant žmogaus požiūrị galima gauti informacijos ir apie organizacinę kultūrą, kuri apima socialines vertybes, dalyvavimo jausmą ir kolegų tarpusavio bendradarbiavimą (Dodji, Mahmoodi, Asadi, 2014). S. Lewio (2003) teigimu, visuomenès vertybės, naujos verslo galimybès, klientų pasitenkinimas, organizacijos reputacija, puikūs santykiai su suinteresuotomis šalimis veikia kaip skirtingos varomosios jègos, kurios motyvuoja verslo organizacijas ịgyvendinti įmonių socialinès atsakomybės (İSA) iniciatyvas tokiose srityse kaip žmogaus ir darbuotojų teisès, aplinkosauga ir korupcija. M. Morsing, M. Schultz (2006) teigimu, ISSA iniciatyvos tampa organizacijos vertybių dalimi ir igyvendinamos kasdienëje veikloje, jos paprastai sukelia teigiamą suinteresuotujų grupių reakciją, tada İSA neprieštarauja išorinių suinteresuotųjų grupių siekiams ir tampa svarbiu instrumentu verslo konkurencinèse varžybose (Juščius, 2009). İSA visuomenès labui padeda sumažinti ar net panaikinti atotrūkị tarp organizacijos ir suinteresuotujų grupių vertybinių nuostatų. Dèl to visuomenès pasitikèjimas tokiomis organizacijomis auga. Pasak J. Jakulevičienès (2012), socialinè atsakomybè yra svarbi, nes mažina sąnaudas (pvz., žaliavų ir energijos išteklių taupymas, mažesnè darbuotojų kaita, išaugęs jų darbo efektyvumas); užtikrina geresnị verslo rizikos valdymą (pvz., mažinama reputacijos praradimo ar priežiūros institucijų sankcijų rizika); padeda užsitarnauti palankesnị klientų požiūrị; pritraukia darbuotojus; kuria geresnị prekinị ženklą; skatina inovacijas (Chawak, Dutta, 2014). Socialiai atsakingose organizacijose darbuotojams sudaroma galimybė mokytis, kurti ir realizuoti save, kaip atlygị už atliekamą darbą gauti ne tik pinigų, bet ir sustiprinti savigarbą, organizacija supranta šeimos ir darbo įsipareigojimų derinimo svarbą, todėl sudaro darbuotojams palankias darbo sąlygas. Tokiose organizacijose puikiai veikia darbuotojų informavimo sistema, darbuotojams suteikiama daugiau igaliojimų, rūpinamasi jų darbingumu ir darbo sauga, didesne darbo ịvairové, suteikiamos lygios teisès ir vienodas atlyginimas moterims ir vyrams (Green paper, 2001). Apibendrinant galima teigti, kad ISA nauda yra ịvairiapusè. Šiuolaikiniame versle ịmonès, siekdamos būti konkurencingos, negali nekreipti dèmesio ị socialinę atsakomybę ar organizacinę kultūrą. Organizacijos egzistuoja tik pritariant visuomenei, todèl kiekviena organizacija turètų vykdyti savo veiklą, keldama kuo mažesnę grèsmę aplinkai ir žmogui.

\section{Tyrimo metodologija}

Siekiant ištirti organizacinès kultūros ir socialinès atsakomybès ịgyvendinimą UAB „Kretingos vandenys“ atliktas kiekybinis tyrimas, apklausa raštu. Klausimyne pateikta dešimt klausimų. Penki klausimai pateikti pagal ranginę skalę, kur 1 reiškia visiška pritarima, 5 - visiška nepritarima. Respondentams pateiktas vienas atvirasis klausimas, kur prašyta parašyti savo nuomonę. Vienu klausimu respondentai galëjo pasirinkti daugiau kaip kelis jiems tinkamus atsakymo variantus. Trys klausimai pateikti siekiant išsiaiškinti respondentų demografinius požymius: respondentų amžių, darbo stažą ir pareigas organizacijoje. Kiekvienam respondentui anketa pateikta individualiai ir paprašyta sudalyvauti apklausoje. Tyrimas vykdytas 2014 m. balandžio mènesị.

İmonejje dirba 85 žmonès. Apklausti 64 įmonès darbuotojai, esant 5 proc. paklaidai. Daugiausiai apklausoje dalyvavo vyrų, nes jie organizacijos sudaro daugumą. Daugiausiai apklausoje dalyvavusių respondentų yra 45-54 metų amžiaus (35,9 proc.), 29,3 proc. - vyresnių nei 55 metų amžiaus, 10,4 proc. apklaustųų nuo 18 iki 25 metų amžiaus, 10,9 proc. apklaustųjų yra nuo 26 iki 34 metų amžiaus ir 35-44 metų amžiaus - 12,5 proc. Darbo stažo aspektu didžiausią apklaustujų dalị sudaré turintieji daugiau kaip 9 metų darbo stažą (34,4 proc.), 25,0 proc. įmonèje dirba nuo 6 iki 9 metų, 18,8 proc. - nuo 1 iki 3 metų, 17,2 proc. - nuo 3 iki 6 metų ir iki 1 metų - tik 4,7 proc. apklaustujų. Pagal užimamas pareigas apklausoje dalyvavo 5,1 proc. aukščiausios grandies vadovų, 11,9 proc. - vidurinès grandies vadovų, 16,9 proc. - žemiausios grandies vadovų ir 66,1 proc. - darbininkai, neturintys pavaldinių.

Gauti duomenys apdoroti SPSS (angl. Statistical Package for the Social Sciences) programa (17.1 versija). Duomenims analizuoti pasirinkta aprašomoji statistika (procentai, vidurkiai [toliau tekste - V], moda). 
Vidurkiams palyginti pasirinkta dispersinè analizè, taikytas ANOVA testas. ANOVA testas parodo kintamujų tarpusavio ryšį, t. y. ar kintamieji yra statistiškai susiję ir daro įtaką vienas kitam: jei reikšmingumo lygmuo $p \leq 0,05$, tai kintamieji vienas kitą veikia, jei $p>0,05-$ ne. Aiškinantis statistinị vidurkių reikšmingumo skirtumą tiems teiginiams, kuriems egzistuoja statistinè sąsaja, analizuojamas ANOVA testo Turkey kriterijus. Siekiant įvertinti klausimyno skalès vidinị nuoseklumą dažniausiai naudojamas Cronbacho alfa (Cronbach's alpha) koeficientas, kuris remiasi pavienių klausimų, sudarančių klausimyną, koreliacija ir ịvertina, ar visi skalès klausimai pakankamai atskleidžia tiriamajị dydį ir leidžia patikslinti reikiamų klausimų skaičių skalèje (Pukènas, 2009).

\section{UAB ,Kretingos vandenys“ organizacinès kultūros ir socialinès atsakomybès} igyvendinimo tyrimo rezultatų analizé

Tyrimu siekta išsiaiškinti darbuotojų požiūrị i i imonès vykdomą ịmonių socialinę atsakomybę bei organizacinę kultūrą. 1 lentelèje pateikta Cronbacho alfa koeficiento reikšmè, kuri tinkamai ir kokybiškai sudarytam klausimynui turètų būti didesnè kaip 0,7 (kai kurių autorių teigimu -0,6). Šiuo atveju analizuojant klausimyno skalių vidinį nuoseklumą gauta, kad cronbacho alfa koeficientas yra didesnis kaip 0,8 . Tai reiškia, kad skalè sudaryta tinkamai.

1 lentele. Klausimyno skalių vidinio nuoseklumo vertinimas

\begin{tabular}{|l|c|c|c|}
\hline \multicolumn{1}{|c|}{ Skalès pavadinimas } & $\begin{array}{c}\text { Cronbacho alfa } \\
\text { koeficientas }\end{array}$ & $\begin{array}{c}\text { Standartizuotư } \\
\text { duomenų Cronbacho } \\
\text { alfa koeficientas }\end{array}$ & $\begin{array}{c}\text { Skalès } \\
\text { klausimu } \\
\text { skaičius }\end{array}$ \\
\hline Teiginiai, susiję su organizacine kultūra & 0,8509 & 0,8485 & 11 \\
\hline Teiginiai, atskleidžiantys İSA naudą & 0,8245 & 0,8366 & 7 \\
\hline Teiginiai, atskleidžiantys İSA privalumus & 0,8641 & 0,8669 & 10 \\
\hline $\begin{array}{l}\text { Teiginiai, atskleidžiantys respondentų nuomones, } \\
\text { kiek organizacija skiria dèmesio tam tikroms sritims }\end{array}$ & 0,8829 & 0,8787 & 12 \\
\hline
\end{tabular}

Šaltinis: sudaryta remiantis 2014 m. atlikto tyrimo rezultatais

Spearman-Brown'o padidinto patikimumo koeficientas įvardytas kaip standartizuotu duomenu cronbacho alfa koeficientas. Kaip matyti 1 lentelèje, jo reikšmè artima Cronbacho alfa koeficiento reikšmei, o tai reiškia, kad atsakymų i paskirus klausimus dispersijos yra panašios.

Respondentų pirmuoju klausimu teirautasi, kiek kiekvienas pateiktas teiginys būdingas jų organizacijai, čia 1 reiškia visiškq sutikima, 5 - visiška nesutikima su pateiktuoju teiginiu. Pateiktoje 2 lentelèje matyti, kad įmonès darbuotojai su daugeliu pateiktų teiginių sutinka tik iš dalies. Respondentai sutinka (moda 2) su tokiais teiginiais kaip: organizacijoje vyksta bendros šventès, kur kviečiami dalyvauti visi darbuotojai ar net jų šeimų nariai (V 2,19); organizacijoje yra daug organizacijos simboliką rodančių daiktų (V 2,28); organizacijoje puoselèjami draugiški ir korektiški santykiai tarp bendradarbių (V 2,31); organizacijos misija aiškiai suformuota (V 2,44); organizacijoje vertinamas lojalumas, patirtis (V 2,46); organizacijoje yra ryškiu lyderių, kuriuos pripažįsta darbuotojai (V 2,52). Iš dalies respondentai sutinka (moda 3), kad organizacijoje daug dèmesio skiriama vertybèms, kurios žinomos visiems darbuotojams (V 2,76). Tik iš dalies organizacijos darbuotojai susipažinę su organizacijos ịkūrimo istorija (V 2,64), darbuotojai organizacijoje tik iš dalies jaučiasi saugūs (V 2,65). Tik iš dalies sutinkama (moda 3), kad sprendimai organizacijoje priimami atsižvelgiant ị daugelio darbuotojų nuomonę (V 3,20). Galima pastebèti, kad organizacijoje ịgyvendinama organizacinè kultūra. Tačiau akcentuotina, kad tam tikra dalis darbuotojų (o tai būtų žemiausios grandies vadovai ir kai kurie darbuotojai, neturintys pavaldinių) teigia, kad nesusipažinę su organizacijos vertybèmis, jos ịkūrimo istorija, todèl siūlytina organizacijos vadovybei labiau akcentuoti šiuos organizacinès kultūros elementus. Vertybės yra nematomas, bet svarbiausias organizacinés kultūros aspektas. Kiekviena organizacija turi vertybių rinkinị, kurị perduoda savo nariams. Teigiama, kad vertybės veikia kaip elgseną stiprinantis veiksnys, aiškiai nurodantis, kaip reikètų elgtis tam tikrose situacijose. Aiškiai apibréžtos vertybės sumažina 
elgesio dviprasmiškumą ir „padeda“ darbuotojams priimti sprendimus. Aptarę ir nuoširdžiai prièmę vertybes darbuotojai elgiasi kūrybiškiau, geriau išnaudoja neapibrèžtų situacijų teikiamas galimybes, sumaniau sprendžia sudėtingas problemas nei tie, kurie griežtai laikosi nustatytų tikslų ir procedūrų. Taigi vadovavimą, kuris remiasi vertybėmis, taikanti organizacija geba lanksčiau prisitaikyti prie aplinkos reikalavimų (Andrijauskaitè, 2003). Tikètina, kad vertybių akcentavimas skatintų darbuotojus labiau ịsipareigojimą organizacijai ir atitinkamai elgtis.

2 lentelé. Darbuotojų požiūris ị organizacijos organizacinę kultūrą (vidurkis, moda, st. nuokrypis, ANOVA testo $\mathrm{p}$ reikšmè)

\begin{tabular}{|c|c|c|c|c|c|}
\hline Nr. & Teiginiai & $\begin{array}{c}\text { Vidurkis } \\
\text { (V) }\end{array}$ & Moda & $\begin{array}{c}\text { St. } \\
\text { nuokrypis }\end{array}$ & $\begin{array}{c}\text { P reikšmè } \\
\text { (užimamos } \\
\text { pareigos) }\end{array}$ \\
\hline 1 & $\begin{array}{l}\text { Daug dėmesio skiriama organizacijos vertybėms, jos } \\
\text { visiems darbuotojams žinomos }\end{array}$ & 2,76 & 3 &, 867 & , 107 \\
\hline 2 & Aiškiai suformuluota organizacijos misija & 2,44 & 2 & ,003 & ,000 \\
\hline 3 & $\begin{array}{l}\text { Organizacijos darbuotojams žinoma organizacijos ịkūrimo } \\
\text { istorija }\end{array}$ & 2,64 & 3 & ,744 &, 592 \\
\hline 4 & $\begin{array}{l}\text { Organizacijoje yra daug organizacijos simboliką } \\
\text { atskleidžiančių daiktų (kalendorių, puodelių, rašiklių ir kt.) }\end{array}$ & 2,28 & 2 &, 878 & ,084 \\
\hline 5 & $\begin{array}{l}\text { Organizacijoje atliekami tam tikri ritualai (pvz., pagerbiami } \\
\text { darbuotojai, švenčiamos šventės ir kt.) }\end{array}$ & 2,43 & 2 &, 057 &, 180 \\
\hline 6 & Organizacijoje vertinamas lojalumas, patirtis & 2,46 & 2 & ,985 & ,202 \\
\hline 7 & $\begin{array}{l}\text { Organizacijoje puoselėjami draugiški ir korektiški santykiai } \\
\text { tarp bendradarbių }\end{array}$ & 2,31 & 2 & ,907 & ,012 \\
\hline 8 & $\begin{array}{l}\text { Organizacijoje yra ryškių lyderių, kuriuos pripažista } \\
\text { darbuotojai }\end{array}$ & 2,52 & 2 &, 841 & ,629 \\
\hline 9 & $\begin{array}{l}\text { Organizacijoje organizuojamos bendros šventės, kur } \\
\text { kviečiami visi darbuotojai ar net jų šeimų nariai }\end{array}$ & 2,19 & 2 & ,702 & ,270 \\
\hline 10 & Dirbdami šioje organizacijoje darbuotojai jaučiasi saugūs & 2,65 & 3 & ,828 & 175 \\
\hline 11 & $\begin{array}{l}\text { Sprendimai organizacijoje priimami atsižvelgus i daugelio } \\
\text { darbuotojų nuomonę }\end{array}$ & 3,20 & 3 &, 105 &, 551 \\
\hline
\end{tabular}

Šaltinis: sudaryta remiantis $2014 \mathrm{~m}$. atlikto tyrimo rezultatais

Aiškinantis, kokie demografiniai duomenys lèmė atitinkamus pasirinkimo variantus, atliktas ANOVA testas. Analizuojant statistinị vidurkių reikšmingumo skirtumą tiems teiginiams, kuriems egzistuoja statistinè sąsaja, taikytas ANOVA testo Turkey kriterijus. 2 lentelëje pateikiama $p$ reikšmé analizuojant duomenis dèl užimamų pareigų. Nustatyta, kad vidurinès ir žemiausios grandies vadovai, lyginant su aukščiausios grandies vadovais, linkę labiau sutikti, kad organizacijoje aiškiai suformuluota misija $(p \leq 0,05=0,000)$. Tačiau negalime teigti, kad aukščiausios grandies vadovai numatytai organizacijos misijai prieštarauja. Bendrai visi darbuotojai teigè, kad misija organizacijoje suformuluota tinkamai (moda 2, žr. lentelę 2). Darbuotojai, neturintys pavaldinių, labiau pritaria, kad organizacijoje yra draugiški ir korektiški santykiai tarp bendradarbių $(p \leq 0,05=0,012)$, tuo tarpu žemiausios grandies vadovai tik iš dalies sutinka su šiuo teiginiu. Tai gali rodyti, kad intensyviau bendrauja bendradarbiai, neturintys pavaldinių, nei žemiausios grandies vadovai. Todėl ir santykiai yra draugiškesni tarp šių darbuotojų.

Darbuotojų teirautasi, kaip organizacijoje keičiamasi informacija. Informacijos sklaida organizacijoje yra labai svarbus organizacinès kultūros aspektas. Tuo parodoma, kokie ryšiai sieja organizacijos narius, kokios priemonės taikomos perduodant informaciją. 
3 lentele. Informacijos keitimasis organizacijoje (galima pasirinkti kelis atsakymo variantus)

\begin{tabular}{|c|l|l|l|}
\hline Nr. & \multicolumn{1}{|c|}{ Pasirinkimo variantai } & Procentai & Pasirinkimo dažnumas, procentais \\
\hline & Reikiamą informaciją gaunu susirinkime & 20,3 & 59,6 \\
\hline & Informaciją gaunu iš kolegų & 22,9 & 67,3 \\
\hline & Informaciją gaunu internetu & 3,9 & 11,5 \\
\hline & Skaitau informaciją, pateiktą skelbimų lentoje & 5,9 & 17,3 \\
\hline & Kas nors pasako, ką daryti & 5,9 & 17,3 \\
\hline & Informaciją perduoda vadovas & 26,1 & 76,9 \\
\hline & Tiesiog dirbu savo darbą - nebūtina visko žinoti & 9,2 & 26,9 \\
\hline & Turime žmogų, kuris praneša visas naujienas & 5,9 & 17,3 \\
\hline
\end{tabular}

Šaltinis: sudaryta remiantis $2014 \mathrm{~m}$. atlikto tyrimo rezultatais

Pateiktoje 3 lentelèje matyti, kad dažniausiai informaciją perduoda vadovas (76,1 proc.); dažnai ji gaunama iš kolegų (67,3 proc.); gana dažnai reikiama informacija gaunama susirinkimų metu $(59,6$ proc.). Rečiausiai rinktasi variantą, kad informacija gaunama internetu (11,5 proc.), perskaitoma skelbimų lentoje (17,3 proc.), kas nors pasako, ką daryti (17,3 proc.). Iš pateiktų atsakymų galima matyti, kad informacija dažniausiai perduodama tiesiogiai vadovo, susirinkimų metu ar kolegų ir tik retais atvejais informacijai perduoti pasitelkiamos tokios priemonès kaip internetas ar skelbimų lentos.

Paklausus darbuotojų, kuo įmonių socialinè atsakomybė naudinga organizacijai, kaip labiausiai svarbios sritys išskirta: tai padeda pritraukti ir išlaikyti geriausius darbuotojus (V 2,40), gerina ịmonès ịvaizdi (V 2,17), prisideda prie geresnès gyvenimo kokybès kūrimo (V 2,30), čia moda 2. Kaip iš dalies svarbios sritys (moda 3) paminèta, kad İSA padeda sumažinti energijos ir atliekų kiekị bei joms skiriamas išlaidas (V 2,56), padeda diferencijuoti verslą (V 2,77), pasiruošti pokyčiams griežtejjant ịstatymams (V 2,51) ir gali padèti atverti naujas rinkas $(2,55)$. Atsakinga verslo praktika gali padèti organizacijai sukurti konkurencini pranašumą, atverti novatoriškas galimybes, sumažinti veiklos sąnaudas. Kai kurių mokslininkų (Juščius, 2007; Kotler, Lee, 2007) teigimu, vienas iš būdų formuoti palankų ịvaizdị visuomenès akyse, kitaip tariant, ne tik laikytis įstatymų, tarptautinių susitarimų ir sutartų elgsenos normų, bet ir siekti didinti visuomenès gerovę, diegti socialiai atsakingo verslo standartus, kuriais vadovaujantis ị savo veiklos vidinius procesus ir išorinius santykius savanoriškai integruoti socialinius, aplinkosaugos ir skaidraus verslo principus. Galima teigti, kad organizacijų, kurios pasiryžusios vykdyti socialiai atsakingas iniciatyvas, nauda yra ịvairiapusè.

Atliktas ANOVA testas atskleidè, kad darbuotojų užimamos pareigos turi įtakos pasirinkimo variantams, kiti demografiniai duomenys pasirinkimo variantams įtakos neturèjo. Vidurinès grandies vadovai labiau linkę manyti, kad I̦SA padeda pasiruošti griežtejant ịstatymams ( $p \leq 0,05=0,026)$, tuo tarpu darbuotojai nelinkę šiam teiginiui pritarti. Aukščiausios grandies vadovai linkę sutikti, kad İSA gerina įmonès įvaizdị $(p \leq 0,05=0,038)$ bei prisideda prie geresnès gyvenimo kokybès kūrimo $(p \leq 0,05=0,047)$, tuo tarpu vidurinès bei žemesnès grandies vadovai mažiau linkę sutikti su šiais teiginiais.

4 lentelè. Socialinès atsakomybès (SA) nauda organizacijai (vidurkis, moda, st. nuokrypis, ANOVA testo $\mathrm{p}$ reikšmė)

\begin{tabular}{|c|c|c|c|c|c|}
\hline Nr. & Teiginiai & Vidurkis & Moda & $\begin{array}{c}\text { St. } \\
\text { nuokrypis }\end{array}$ & $\begin{array}{c}\text { P reikšmė } \\
\text { (užimamos } \\
\text { pareigos) }\end{array}$ \\
\hline 1 & $\begin{array}{l}\text { Padeda sumažinti energijos ir atliekų kiekị bei joms } \\
\text { skiriamas išlaidas }\end{array}$ & 2,56 & 3 & ,879 & ,356 \\
\hline 2 & Padeda diferencijuoti verslą & 2,77 & 3 & ,750 & , 157 \\
\hline 3 & Padeda pasiruošti pokyčiams griežtèjant įstatymams & 2,51 & 3 & ,639 & ,026 \\
\hline 4 & Gali padèti atverti naujas rinkas & 2,55 & 3 & ,889 & ,311 \\
\hline 5 & Padeda pritraukti ir išlaikyti geriausius darbuotojus & 2,40 & 2 & 947 & 238 \\
\hline 6 & Gerina ịmonès įvaizdi & 2,17 & 2 & ,672 & ,038 \\
\hline 7 & Prisideda prie gyvenimo kokybės gerinimo & 2,30 & 2 & 890 & ,047 \\
\hline
\end{tabular}

Šaltinis: sudaryta remiantis $2014 \mathrm{~m}$. atlikto tyrimo rezultatais 
Darbuotojų teirautasi, kokie, jų manymu, pagrindiniai motyvai organizacijai būti socialiai atsakinga. Darbuotojai minèjo ịvairius motyvus, dèl ko organizacijai verta tokia būti. Darbuotojų manymu, tai padeda laikytis darbo drausmès, gaunama ekonominè nauda, gerinamas įmonès ịvaizdis, paisoma etiško elgesio, lojalumo principų, didesnė motyvacija, padeda išlaikyti gerus darbuotojus, ilgalaikis ịsipareigojimas etiškai elgtis ir prisidèti prie geresnès darbuotojų, klientų bei aplinkos kokybės kūrimo. Akcentuotina, kad SA veikla prisideda prie organizacijos žinomumo didinimo ir padeda kurti įmonès, kaip atsakingo rinkos dalyvio, ìvaizdị. Organizacija savo misijoje akcentuoja, kad ịsipareigoja savo abonentams teikti efektyviausiai jų poreikius tenkinančias paslaugas, siekdamos gerinti jų gyvenimo kokybę, šalies vandentvarkos paslaugų sektoriuje diegti etiškos ir skaidrios veiklos principus. Tai ir parodo šios organizacijos įsipareigojimų sritis socialiai atsakingoje veikloje.

Respondentų teirautasi, kokie, jų nuomone, yra didžiausi sunkumai, su kuriais susiduria organizacija (5 lentelè). Pasak respondentų tai būtų reikalingų žinių trūkumas ịgyvendinant socialinę atsakomybę (V 2,36) bei organizacijai keliami didesni reikalavimai (V 2,34), moda 2. Iš dalies respondentai sutinka (moda 3), kad didèja veiklos sąnaudos (V 2,60), neigiama įtaka pelnui (V 2,89), be to, darbuotojams tai yra papildomas darbas (V 2,62).

5 lentelè. Didžiausi sunkumai, su kuriais susiduria organizacija ịgyvendindama socialinę atsakomybę (vidurkis, moda, st. nuokrypis)

\begin{tabular}{|l|l|r|r|r|}
\hline Nr. & \multicolumn{1}{|c|}{ Kriterijai } & Vidurkis & \multicolumn{1}{c|}{ Moda } & \multicolumn{1}{c|}{ St. nuokrypis } \\
\hline 1 & Didëja veiklos sąnaudos & 2,60 & 3 &, 689 \\
\hline 2 & Neigiama įtaka pelnui & 2,89 & 3 &, 891 \\
\hline 3 & Organizacijai keliami didesni reikalavimai & 2,34 & 2 &, 678 \\
\hline 4 & Reikalingų žinių trūkumas įgyvendinant socialinę atsakomybę & 2,36 & 2 &, 831 \\
\hline 5 & Darbuotojams - papildomas darbas & 2,62 & 3 &, 860 \\
\hline
\end{tabular}

Šaltinis: sudaryta remiantis $2014 \mathrm{~m}$. atlikto tyrimo rezultatais

Tokia respondentų nuomonė rodo, kad socialinės atsakomybės ịgyvendinimas organizacijoje nesukelia didelių sunkumų. Visoms organizacijoms, igyvendinančioms İSA, keliami didesni reikalavimai, tačiau nereikètų pamiršti, kad organizacijos savanoriškai įsipareigoja dalyvauti šioje iniciatyvoje. Daugumai organizacijų trūksta žinių ịgyvendinti socialinę atsakomybę, todèl visiškai natūralu, kad ir šios organizacijos darbuotojams tokių žinių trūksta. Galima teigti, kad darbuotojai įžvelgia pagrịstus İSA sunkumus, kartu suvokdami, kad İSA nedaro neigiamos įtakos pelnui, tai darbuotojams nèra papildomas darbas ir veiklos sąnaudos nedidèja. Todèl respondentų ịvertinimai leidžia daryti išvadą, kad apklaustieji analizuojamoje organizacijoje įžvelgia daugiau privalumų nei trūkumų, tai atskleidžia 6 lenteleje pateikti duomenys.

6 lentele. Organizacijų, igyvendinančių socialinę atsakomybę, privalumai

(vidurkis, moda, st. nuokrypis, ANOVA testo p reikšmè)

\begin{tabular}{|l|l|r|r|r|r|}
\hline Nr. & \multicolumn{1}{|c|}{ Kriterijai } & Vidurkis & Moda & St. nuokrypis & $\begin{array}{c}\text { P reikšmé } \\
\text { (užimamos } \\
\text { pareigos) }\end{array}$ \\
\hline 1 & Tinkamo pavyzdžio rodymas & 2,22 & 2 &, 769 &, 099 \\
\hline 2 & Geresnis įmonės įvaizdis & 2,06 & 2 &, 763 &, 725 \\
\hline 3 & Didesnis darbuotojų lojalumas & 2,24 & 2 &, 001 \\
\hline 4 & $\begin{array}{l}\text { Mažesnės sąnaudos (pvz., padeda sumažinti } \\
\text { elektros atliekų kiekị bei joms skiriamas išlaidas) }\end{array}$ & 2,41 & 2 &, 981 &, $\mathbf{0 0 7}$ \\
\hline 5 & $\begin{array}{l}\text { Didesnis produktyvumas ir geresnė teikiamų } \\
\text { paslaugų kokybe }\end{array}$ & 2,22 & 2 &, 839 &, $\mathbf{0 0 4}$ \\
\hline 6 & Geresni santykiai su bendruomene & 2,17 & 2 &, 746 &, 171 \\
\hline 7 & Didinamas šalies konkurencingumas & 2,41 & 2 &, 714 &, 044 \\
\hline 8 & Geresnės gyvenimo kokybės kūrimas & 2,15 & 2 &, 878 &, 052 \\
\hline 9 & Skaidri ir etiška verslo praktika & 2,26 & 2 &, 757 &, 591 \\
\hline
\end{tabular}

Šltinis: sudaryta remiantis $2014 \mathrm{~m}$. atlikto tyrimo rezultatais 
Analizuojant respondentų pasisakymus, kokie didžiausi organizacijų, igyvendinančių socialinę atsakomybę, privalumai, pateiktoje 6 lenteleje matyti, kad su visais minètais teiginiais darbuotojai sutinka (moda 2). Tai rodo, kad darbuotojai ịžvelgia gana daug privalumų organizacijose, kuriose ịgyvendinama socialinè atsakomybè.

Atliktas ANOVA testas atskleidè, kad užimamos pareigos turi įtakos kai kuriems pasirinkimo variantams. Turkey kriterijus parodè, kad statistinè sąsaja su darbuotojų užimamomis pareigomis egzistuoja šiems teiginiams: didesnis darbuotojų lojalumas ( $p \leq 0,05=0,001)$; mažesnès sąnaudos $(p \leq 0,05=0,007)$; didesnis produktyvumas ir geresnè kokybė teikiant paslaugas $(p \leq 0,05=0,004)$; didinamas šalies konkurencingumas $(p \leq 0,05=0,044)$. Vidurinès, žemiausios grandies vadovai ir darbuotojai, neturintys pavaldinių, labiau linkę sutikti, kad organizacijos, kuri igyvendina İSA principus, darbuotojai yra lojalesni, tuo tarpu aukščiausios grandies vadovai su šiuo teiginiu sutinka mažiausiai. Dẻl mažesnių veiklos sąnaudų labiau sutinka žemiausios grandies vadovai, tuo tarpu aukščiausios ir vidurinès grandies vadovai linkę tik iš dalies pritarti šiam teiginiui. Vidurinès ir žemiausios grandies vadovai linkę pritarti, kad socialiai atsakingoms organizacijoms būdingas didesnis produktyvumas ir geresnè paslaugų kokybė, tuo tarpu aukščiausios grandies vadovai linkę tik iš dalies sutikti su šiuo teiginiu. Kad didinamas šalies konkurencingumas, labiausiai pritaria žemiausios grandies vadovai, lyginant su aukščiausios grandies vadovais.

Apklaustiesiems pateikta skale ir prašyta ịvertinti, kiek, jų nuomone, organizacijoje skiriama dèmesio tam tikroms sritims, kurios atskleidžia SA principų ir organizacinès kultūros igyvendinimą organizacijoje, čia 1 reiškia labai mažai, 5 - labai daug (7 lentelè). Apklaustujų teigimu, organizacija labai mažai (moda 1) dèmesio skiria kovai su kyšininkavimu ir papirkinejjimu (V 1,37); lèšų skyrimui labdarai, rèmimui, paramai (V 1,4); naujų darbo vietų kūrimui $(1,5)$. Vidutiniškai dèmesio (moda 3) skiriama kitoms paminètoms sritims, kaip: visuomenès poreikių tenkinimui (V 2,96); atliekamo darbo kokybei (V 3,06); darbuotojų kvalifikacijai ir motyvacijai (V 2,93); savo vartotojų (klientų) poreikių tenkinimui (V 3,17); savo prekès ar paslaugos pardavimų apimtims didinti (V 3,22), aplinkos apsaugai gerinti (V 3,41), saugių ir sveikų darbo sąlygų užtikrinimui (V 2,93), lygių teisių užtikrinimui (V 2,70), taip pat organizacinès kultūros kūrimui ir tobulinimui (V 3,04). Kaip matyti, organizacija labiau susitelkusi ties vidiniais savo procesais, kaip darbo kokybė, darbuotojų motyvacija, sauga ir sveikata. Akcentuotina, kad šios organizacijos akcijos priklauso miesto savivaldybei, todèl tikètina, kad organizacijos veikimo laisvé ribojama.

7 lentelè. Organizacijos skiriamas dèmesys pateiktoms sritims

(vidurkis, moda, st. nuokrypis, ANOVOS testo p reikšmè)

\begin{tabular}{|c|c|c|c|c|c|}
\hline Nr. & Teiginiai & Vidurkis & Moda & $\begin{array}{l}\text { St. } \\
\text { nuokrypis }\end{array}$ & $\begin{array}{l}p \text { reikšmė } \\
\text { (užimamos } \\
\text { pareigos) }\end{array}$ \\
\hline & Visuomenès poreikiams tenkinti & 2,96 & 3 & ,846 & 800 \\
\hline & Atliekamo darbo kokybei & 3,06 & 3 & ,763 & ,002 \\
\hline & Darbuotojų kvalifikacijai ir motyvacijai & 2,93 & 3 & 887 & ,002 \\
\hline & Savo vartotojų (klientų) poreikiams tenkinti & 3,17 & 3 & ,720 & ,008 \\
\hline & Savo prekės ar paslaugos pardavimų apimtims didinti & 3,22 & 3 & ,718 & 619 \\
\hline & Aplinkos apsaugai gerinti & 3,41 & 3 & ,790 & ,072 \\
\hline & $\begin{array}{l}\text { Saugioms ir sveikoms (ergonomiškoms) darbo sąlygoms } \\
\text { užtikrinti }\end{array}$ & 2,93 & 3 & ,843 & ,031 \\
\hline & $\begin{array}{l}\text { Kovai su kyšininkavimu, papirkinèjimu, kitomis } \\
\text { korupcijos rūšimis }\end{array}$ & 1,37 & 1 & , 186 & ,237 \\
\hline & $\begin{array}{l}\text { Užtikrinti lygias teises, laikantis LR Konstitucijoje ir } \\
\text { darbo isstatymuose nustatytų diskriminacijos pagal amžiu, } \\
\text { lytį, kilmę normų }\end{array}$ & 2,70 & 3 & ,890 & ,059 \\
\hline & Organizacinei kultūrai kurti ir puoselèti & 3,04 & 3 & ,985 &, 405 \\
\hline & Lèšų labdarai skyrimui, rèmimui, paramai & 1,4 & 1 & ,929 &, 150 \\
\hline & Naujoms darbo vietoms kurti & 1,5 & 1 & ,310 & ,018 \\
\hline
\end{tabular}


Atliktas ANOVA testo Turkey kriterijus atskleidè, kad aukščiausios ir vidurinės grandies vadovai labiausiai pritaria tam, kad organizacijoje gana daug demesio skiriama atliekamo darbo kokybei $(p \leq 0,05=0,002)$, darbuotojų kvalifikacijai ir motyvacijai $(p \leq 0,05=0,002)$, savo vartotojų poreikių tenkinimui $(p \leq 0,05=0,008)$, saugių bei sveikų darbo sąlygų užtikrinimui $(p \leq 0,05=0,031)$, tuo tarpu žemiausios grandies vadovai ir darbuotojai, neturintys pavaldinių, linkę šiems teiginiams nepritarti. Kad organizacijoje didelis dèmesys skiriamas naujų darbo vietų kūrimui, labiausiai pritaria aukščiausios grandies vadovai $(p \leq 0,05=0,018)$, lyginant su žemiausios grandies vadovais. Galima būtų teigti, kad darbuotojai su kai kuriomis organizacijos veiklos sritimis (pvz., naujų darbo vietų kūrimas) nesupažindinami arba tiesiog organizacijoje nepriimtina informuoti apie visas vykstančias veiklas, todèl ir išskirti teiginiai vertinami tik vidutiniškai. Organizacijai rekomenduojama darbuotojus labiau įtraukti ị kai kurių sričių ịgyvendinimą, kaip organizacinès kultūros kūrimą ir tobulinimą, aplinkos apsaugos gerinimą ir pan. Be to, daugiau dèmesio galètų būti skiriama kovai su kyšininkavimu, papirkinèjimu, tai leistų organizacijai įtvirtinti savo socialinę atsakomybę visuomenèje, prisidedant prie šių veiklų igyvendinimo.

Išvados

Galima teigti, kad organizacinės kultūros ir įmonių socialinės atsakomybės ịgyvendinimas padeda organizacijoms siekti užsibrèžtų tikslų. Vykdydamos socialiai atsakingą veiklą, organizacijos ne tik prisideda prie darnos bendruomenèse kūrimo, socialinès nelygybès mažinimo, švarios aplinkos palaikymo, bet ir sudaro darbuotojams palankias darbo sąlygas, kad kiekvienas organizacijoje dirbantis asmuo jaustųsi reikalingas, matytų darbo perspektyvas ir būtų motyvuotas. Be to, organizacijos, puoselèdamos organizacinę kultūrą ir stiprindamos socialinę atsakomybę, kelia organizacijos reputaciją, gerina ịvaizdį tiek darbuotojų, tiek visuomenès akyse. Organizacinès kultūros ir socialinès atsakomybès ịgyvendinimas organizacijose yra esminis konkurencinio pranašumo šaltinis ir turi įtakos darbuotojų motyvacijai bei darbo našumui.

Tyrimu nustatyta, kad organizacinei kultūrai puoselèti organizacijoje skiriama mažai dẻmesio. Dalis darbuotojų nesusipažinę su organizacijos ịkūrimo istorija, vertybėmis, kuriomis vadovaujasi organizacija, dirbdami šioje organizacijoje jaučiasi nesaugūs. Tobulinant organizacinès kultūros valdymą rekomenduojama viešinti vertybes, kurias organizacija puoselèja, supažindinti darbuotojus su organizacijos ịkūrimo istorija, taip parodant darbuotojams, kas šioje organizacijoje svarbiausia. Ištyrus, kaip organizacijoje igyvendinama socialinè atsakomybè, pastebèta, kad ši iniciatyva igyvendinama pakankamai intensyviai. Didelis dèmesys skiriamas santykiams su bendruomene, skaidriai ir etiškai verslo praktikai, darbuotojų lojalumui užtikrinti ir pan. Pagrindiniai sunkumai, su kuriais susiduriama organizacijoje, - būtinų žinių trūkumas, ịgyvendinant socialinę atsakomybę, papildomas darbas darbuotojams. Daugelio darbuotojų teigimu, organizacija mažai dèmesio skiria kovai su kyšininkavimu, papirkinejjimu ir pan. Todèl rekomenduojama organizacijai didesnị dèmesį skirti darbuotojų mokymams socialinès atsakomybės tematika, taip pat numatyti korupcijos valdymo priemones, nes tai yra vienas svarbesnių socialinès atsakomybès įgyvendinimo principų. Taip organizacija sustiprintų savo įvaizdị ir pakeltų reputaciją visuomenėje, būdama pavyzdžiu kitoms organizacijoms.

\section{Literatūra}

Ahmad, M. S. (2012). Impact of organizational culture on performance management practices in pakistan. Business Intelligence Journal, Vol. 5 (1), p. 50-55.

Chawak, S., Dutta, D. (2014). Corporate Social Responsibility: Trends and Callenges. Abhinav International Monthly Refereed Journal of Research in Management and Technology, Vol. 3 (4), p. 32-39.

Chang, K., Lu, L. (2007). Characteristics of organizational culture, stressors and wellbeing: The case of Taiwanese organizations. Journal of Managerial Psychology, Vol. 22 (6), p. 549-568.

Dodji, M. S., Mahmoodi, M., Asadi, A. A. (2014). Investigation of the relation between organizational culture, financial management tenure and financial performance with corporate social responsibility (CSR). Interdisciplinary Journal of Contemporary Research in Business, Vol. 15 (12), p. 354-367.

Ehtesham, U. M., Muhammad, T. M., Muhammad, S. A. (2011). Relationship between Organizational Culture and Performance Management Practices: A Case of University in Pakistan. Journal of Competitiveness, Vol. 4, p. 78-86. 
Gregory, B. T., Harris, S. G., Armenakis, A. A., Shook, Ch. L. (2009). Organizational culture and effectiveness: A study of values, attitudes, and organizational outcomes. Journal of Business Research, Vol. 62 (7), p. 673-679.

Green Paper. (2001). Promoting a European framework for corporate social responsibility. Commission of the European Communities. Brussels. Prieiga internete: http://ew.eea.europa.eu/Industry/Reporting/ceccorporate_responsibility/com2001_0366en01.pdf

Gupta, B. (2011). A Comparative Study of Organizational Strategy and Culture Across Industry. Benchmarking: An International Journal, Vol. 18 (4), p. 510-528.

Jakulevičienè, J. (2012). Kas yra įmonių socialinè atsakomybė? Atsakingas verslas, ịmoniu socialinès atsakomybès igyvendinimas ir nauda, Nr. 5, p. 2-16. Prieiga internete: http://www.undp.lt/uploads/Publications\%20LT/Atsakingas\%20verslas_NR5.pdf

Juščius, V. (2009). Imonių socialinė atsakomybė ir organizacijų tapatumas šiuolaikinės ekonominės krizės kontekste. Ekonomika ir vadyba, Nr. 14, p. 264-271.

Kotler, Ph., Lee, N. (2007). Doing the Most Good to Your Company. Corporate Social Responsibility. New Jersey: John Wiley \& Sons.

Lee, K. J., Yu, K. (2004). Corporate culture and organizational performance. Journal of Managerial Psychology, Vol. 19 (4), p. 340-359.

Lewis, S. (2003). Reputation and corporate responsibility. Journal of Communication Management, Vol. 7 (4), p. $356-366$.

Lund, D. B. (2003). Organizational culture and job satisfaction. Journal of Business \& Industrial Marketing, Vol. 18 (3), p. 219-236.

Macintosh, E., Doherty, A. (2007). Estending the Scope of Organizational Culture: The External Perception of an Internal Phenomenon. Sport Management Review, Vol. 10, p. 45-64.

Morsing, M., Schultz, M. (2006). Corporate social responsibility communication: stakeholder information, re-sponse and involvement strategies. Business Ethics: A European Review, Vol. 15 (4), p. 323-338.

Nango, E. S., Ikyanyon, D. N. (2012). The Influence of Corporate Culture on Employee Commitment to the Organization. International Journal of Business and Management, Vol. 7 (22), p. 21-28.

Osland, J. S., Turner, M. E., Kolb, D. A., Rubin, I. M. (2007). The Organizational Behavior Reader. New Jersey: Upper Saddle River.

Pukėnas, K. (2009). Kokybinių duomenu analizè SPSS programa. Kaunas: Lietuvos kūno kultūros akademija.

Stanic, V., Boyle, D. (2000). Developing people and the corporate culture in financial services. Woodhead publishing limited.

Šimanskienè, L. (2008). Organizacinès kultūros poveikis organizacijų valdymui. Vadybos mokslas ir studijos - kaimo versly ir ju infrastruktūros plètrai, Nr. 15 (4), p. 1-6.

\title{
CONDITION OF THE ORGANIZATIONAL CULTURE AND CORPORATE SOCIAL RESPONSIBILITY OF LLC "KRETINGOS VANDENYS"
}

\author{
Jurgita Paužuoliené, Jolanda Daubariené \\ Klaipėdos universitetas, Klaipėdos valstybinè kolegija(Lietuva)
}

\section{Summary}

Organizational culture and corporate social responsibility are effective measures that have an impact on organizational performance and results. In particular norms, principles, rules and values of the organization's employees are more efficient, more comfortable, reduces mistrust, tension, a feeling of insecurity. Organizational culture includes the efforts of all staff, based on common human values. Employees tend to work in organizations where they are treated fairly, respecting their interests. It is ideology of social responsible (SR) organizations. Social responsible organizations promote a business friendly environment to create a social atmosphere, harmonize working relationships and actively participate in social dialogue with the public and with the organization.

The purpose of this article: To investigate the LLC "Kretingos vandenys" organizational culture and the implementation of social responsibility in order to ascertain the strengths and challenges, as well as providing recommendations for improvement of the analyzed areas. 
Tasks: Analyze the organizational culture and corporate social responsibility in theoretical aspect.

Investigate the LLC "Kretingos vandenys" organizational culture and the implementation of social responsibility, benefits and challenges.

Methods: A literature analysis, systematization, questionnaire, data analysis using the SPSS program.

In order to study the organizational culture and the implementation of social responsibility in the LLC "Kretingos vandenys" was done a quantitative analysis, questionnaire survey. The questionnaire contains ten questions. Five questions are ordinal scale where 1 means full support, 5 full disagreement. One question was given open, where respondents were asked to write their views. And one question, respondents could choose more than a few answers. Three questions are asked in order to find out the demographic characteristics of respondents (age, work experience and position in an organization). Each respondent was asked individual to participate in the survey. The study was done in 2014. April.

The company employs 85 people. Questioning 64 employees of the company, at 5 percent. error. Who participated in the survey are most men, mainly because of the employees of an organization it is a male. Most survey respondents are from 45 to 54 years old (35.9 percent), 29.3 percent more than 55 years of age, 10.4 percent respondents are between 18 and 25 years of age, 10.9 percent respondents between 26 and 34 years of age and 12.5 percent 35-44 years of age. Most respondent have more than 9 years of experience (34.4 percent), 25.0 percent employs between 6 and 9 years old, 18.8 percent from 1 to 3 years, 17.2 percent from 3 to 6 years and up to 1 year working only 4.7 percent of the respondents. According to respondents position in the survey attended by 5.1 percent. senior managers, 11.9 percent. middle managers, 16.9 percent. the lower-level managers and 66.1 percent workers without subordinates.

The data of the questionnaire was processed by SPSS (Special Package for Social Science, 17.1 version) program using descriptive statistics such as frequencies command to determine percentiles, measures of central tendency (mean, median and mode), measures of dispersion (range, standard deviation. Also, data was processed by one-factorial dispersal analysis (ANOVA). The one-way ANOVA compares the means between the interested groups and determines whether any of those means are significantly different from each other. If the significance level of $p \leq 0.05$, the variables affect each other if $p>0.05-$ no. Analyzing the statistical significance of the difference between the averages of those statements for which are statistically related, are analyzed by ANOVA test, Turkey criteria. Internal consistency of the scales of the questionnaire was assessed by the Cronbach alpha (Cronbach's alpha) coefficient. Cronbach's alpha known as an internal consistency estimate of reliability of test scores. The analysis of questioner of this survey revealed that Cronbach's alpha reliability coefficient of scales in the questionnaire is more than $>0.8$ what means that internal consistency of the statements in the scales are excellent.

The study show that for organizational culture in the organization respondents give a medium priority. The implementation of social responsibility is intensive. An employee sees more benefits than problems in the implementation of social responsibility in the organization. The main difficulties implementing social responsibility in the organization are the operating expenses increase, the negative impact on profits and the extra work of employees. However, the main attentions are given to the relationship with the community in a transparent and ethical business practices to ensure the loyalty of employees and so on. The main difficulties encountered in the organization are the lack of the necessary knowledge for the implementation of the social responsibility, and the extra work for employees. Employee opinion the main reasons for an organization to be socially responsible is it helps to maintain work discipline, economic benefits, improving the company's image, respected ethical behavior, loyalty and so on. Organizations are encouraged to pay more attention to organizational culture. Promoting the values that guide the organization to familiarize employees with the organization's story, thus indicating what is important to employees in the organization.

KEY WORDS: organizactional culture, social responsibility, organization.

JEL CODES: M14, L2. 